

\title{
Research Article: Extent of adoption of management practices of Deoni cattle and non-descriptive cattle by the rearers
}

\section{B.L. PISURE, P.R. DESHMUKH AND R.P. KADAM}

Article Chronicle: Received :

20.11.2016;

Revised :

09.12.2016;

Accepted :

17.12.2016

KEY WoRds:

Utility perception, Dairy farmers, Dairy, deoni cattle, Cattle rearers, Dairy enterprise

Author for correspondence :

\section{B.L.PISURE}

Department of Extension Education, College of Agriculture, Vasantrao Naik

Marathwada Krishi

Vidyapeeth, PARBHANI

(M.S.) INDIA

Email:blpisure11@gmail. com; braj_agri@ rediffmailcom

See end of the article for authors' affiliations
SUMMARY : The present study was conducted purposively in Latur district of the Marathwada region of Maharashtra state. From this district six tahsils were selected. Four villages from each taluka were selected purposively. The total villages for the study were 24 . Ten respondents from each village were selected purposively for the study. Comprising 120 respondents of Deoni cattle and 120 respondents of non-descriptive cattle from Latur district were selected. Thus, there were a total of 240 respondents selected for the research study. Ex-post facto research design was adopted in this study. The data were collected with the help of pretested interview schedule. The statistical methods and tests such as frequency, percentage, mean, standard deviation, co-efficient of correlation, multiple regressions, $\mathrm{Z}$ test and path analysis were used for the analysis of data. It was found that more than three fourth $(70.00 \%)$ of deoni cattle rearers and two third $(66.66 \%)$ of non-descriptive cattle rearers had medium level of overall adoption of different cattle management practices for cattle rearing.

How to cite this article : Pisure, B.L., Deshmukh, P.R. and Kadam, R.P. (2017). Extent of adoption of management practices of Deoni cattle and non-descriptive cattle by the rearers. Agric. Update, 12(1): 31-39; DOI : 10.15740/ HAS/AU/12.1/31-39. 